\title{
Cinsiyet ve Sınıf Düzeyinin Yazma Konusu Seçimindeki Rolü
}

\author{
The Role of Gender and Grade Level on Topic Selection in Writing
}

Demet SEBAN*

Öz: Bu çalışmanın amacı, süreç temelli yazma eğitimi almış öğrencilerin farklı metin türlerinde seçtikleri yazma konularını sınıf düzeyi ve cinsiyet değişkenlerine göre incelemektedir. Öğrencilerin 2, 3 ve 4. sınıfta yazdıkları farklı türlerdeki metinler araştırmanın verilerini oluşturmuştur. Araştırma için toplam 305 yazılı metin incelenmiştir. Dokümanlar içerik analizi yapılarak analiz edilmiştir. Araştırma kapsamında öğrencilerin yaşantıları ve bilgi sahibi olduğu konular ile ilgili daha çok ve sürekli yazdıkları bulgulanmıştır. Erkekler ve kızların konu tercihlerinin farklılaştığı ve yazma konularının kalıplaşmış cinsiyet rollerini yansıttığ 1 görülmüştür. Ayrıca üst sınıflara doğru konu sayılarının arttığı ve farklılaştığ izlenmiştir. Öğretmenlerin, konu seçiminde sınıf düzeyine göre değişen öğrencinin tecrübe, ilgi ve ihtiyaçlarını dikkate alması; önyargı ve kalıplaşmış cinsiyet rolleri içeren yazıları sorgulamalarına firsat verecek sınıf ortamları düzenlemeleri araştırmanın önerileri arasındadır.

Anahtar sözcükler: Yazma, Konu Seçimi, Cinsiyet, Sınıf Düzeyi

\begin{abstract}
The purpose of this study was to examine the preferred writing topics of students in different writing genres and the effect of gender and grade level upon the students' selection in choosing their own topics. The data consists of $2^{\text {nd }}, 3^{\text {rd }}$ and $4^{\text {th }}$ grade students' written texts. A total of 350 documents written by students were analyzed using conventional content analysis. The results indicate that students preferred to write mainly on topics related to their own life experience and on the topics that they are more knowledgeable about and interested in. The choice of topic for free writing varied according to the students' gender and grade level. Gender stereotypes were exposed through the choices made in topic selection. When teaching writing, teachers need to think about both the grade level and the students' interests. They also need to be aware of the role of gender in topic selection in order to create an environment for students to question and to deconstruct their written products that recreate gender stereotypes.
\end{abstract}

Keywords: Writing, Topic Selection, Gender, Grade Level

Süreç temelli yazma eğitimi Emig (1971), Garves (1983), Murray (1984), Flower ve Hayes (1981) gibi araştırmacıların kuramları çerçevesinde tartışılmıştır. Söz konusu tartışmaların bir sonucu olarak yazmanın bir süreç olduğu ve iyi bir yazma eğitimi için gerekli aşamaların bulunduğu belirtilmiştir. $\mathrm{Bu}$ aşamalar temel olarak yazma öncesi hazırlık ve planlama, taslak oluşturma (metinleştirme), gözden geçirme, düzenleme ve paylaşma olarak tanımlanmıştır.

Süreç temelli yazma eğitimi yaklaşımına göre hazırlık ve planlama aşamasında öğrencilerin yazacakları konuları seçme konusunda özgür bırakılmaları, metnin içeriğini başarılı bir biçimde yapılandırabilmelerinde önemli bir unsurdur. Graves (1983) öğrencilerin en iyi bildikleri konularda yazabileceğini, başkalarının merak ettiği ve yazmalarını istediği konular hakkında yazma-

\footnotetext{
* Yrd. Doç. Dr., Akdeniz Üniversitesi, Eğitim Fakültesi, İlköğretim Bölümü, Antalya. dseban@akdeniz.edu.tr
} 
nın motivasyonlarını düşüreceğini belirtmiştir. Özellikle küçük yaşlarda yazma çalışmalarının çoğunun öğrencilerin kendi seçtikleri konular esas alınarak yürütülmesi vurgulanmıştır. Böylece öğrencilerin yaşantıları ve gözlemleri ile sahip oldukları bilgilerin yazma becerilerini arttıracağ 1 belirtilmiştir (Lee 1987). Öğrencilerin kendi yaşamlarında olup bitenleri anlatmaları ve iletişim kurmak için yazmayı bir araç olarak kullanmaları daha fazla ve iyi yazmak için itici bir güç olmaktadır (Dyson 1995). Ayrıca öğrencilerin yazma becerileri arasındaki farklılıkların yaşları ve yazdıkları konu hakkındaki bilgilerinden kaynaklandığı bulunmuştur (McCutchen 1986).

Öğrencilerin yazma konusuna kendilerinin mi yoksa öğretmenlerinin mi karar vermeleri gerektiği araştırmacılar tarafından tartışılan önemli konulardan olmuştur (Lee 1987; Flowerday, Schraw \& Stevens 2004). Bununla birlikte konu seçimi ile ilgili yapılan araştırmalar çoğunlukla cinsiyet ile ilişkili olarak ele alınmıştır (Peterson 2006).

Kamler (1993) yazmada serbest konu seçiminin araştırmalarda çok daha derinlemesine ele alınması gerektiğinin altını çizmiştir. Yazmada konu tercihi yazarın cinsiyetinden bağımsız ve doğal olarak gelişmemektedir. Eğer doğal olarak geliştiği kabul edilerek yazma eğitimi verilirse kültürel olarak aktarılan cinsiyet ile ilgili önyargı ve kalıplaşmış rollerin sınıfta yeniden üretileceğini belirtmiştir. Ayrıca cinsiyet ve kimlik gelişiminin, ev okul ve medyadan etkilendiğini dolayısıyla da çocukların konu seçimindeki özgürlüğünün "sözde" kalacağını ifade etmiştir. Çalışmasında, farklı metin türlerinde ne kadar farklı konu seçilirse seçilsin, öğrencilerin yazarken cinsiyetlerine göre konular seçtiklerini ve cinsiyet ile ilgili kimliklerini yapılandırdıklarını belirtmiştir. Öğrencilerin yazma etkinlikleri ile ilgili yaptıkları serbest tartışmalarda kızların daha çok alışveriş, bebekler ve kıyafetler ile ilgili konuları, erkeklerin genelde arabalar, video oyunları ve çizgi film kahramanları ile ilgili konuları seçtikleri görülmüştür (Keenan, Solsken \& Willet 1999). Aile, yakın çevre ve ilişkiler ile ilgili konular daha çok kızlar tarafından tercih edilirken erkekler daha uzak çevre, macera ve spor ile ilgili konularda yazmaktadır (Tuck et al. 1985; Freedman 1995; Peterson 2000).

İkinci sınıflar ile ilgili yaptığı çalışmasında McAuliffe (1994) kız ve erkek öğrencilerin öykülerinde kullandıkları dil ve stili incelemiş; kızların "sosyal ilişkileri", erkeklerin ise daha çok "mücadeleyi" içerecek konular seçtiklerini; karakter seçimlerinde ve rollerinde cinsiyete göre farklı tercihlerde bulunduklarını bulgulamıştır. Deshon'un (1997) birinci sınıf öğrencileri ile yaptığı çalışmasının sonuçlarından biri öğrencilerin süreç temelli yazma uygulamalarında konu seçimi de dâhil özgür bırakılmasının, sınıf içinde sosyal ilişkilerde baskın grubun daha baskın hale gelmesine ve çekimser olan grubun daha fazla ezilmesine katkıda bulunduğudur. Lensmire (1994) ilkokul üçüncü sınıf öğrencilerine süreç temeli yazma eğitimi vermiş ve bir yıl boyunca yapılan çalışmaları değerlendirmiştir. Yazma eğitiminin riskli bir süreç olduğunu vurgulamıştır. Öğrencilerin yazmak için seçtikleri konuların birbirlerini tanımalarına ve eleştirmelerine katkıda bulunduğunun; konu seçiminin okur seçme ve sınıf içinde baskın olabilecek bir statü için araç olarak kullanıldığının altını çizmiştir. Cinsiyetin, sosyoekonomik statünün ve sınıf içindeki baskın rolün konu seçimi üzerine etkili olduğunu ve rollerin yazma sürecinde belirginleştiğini belirtmiştir.

Süreç temelli yazma çalışmalarının etkin bir biçimde uygulanması ile birlikte serbest konu seçimi birçok yönden irdelenmiştir. Günümüze en yakın çalışma ise kırsal kesimde ve şehirde yaşayan ortaokul öğrencilerinin konu seçimleri üzerine yapılmıştır (Shippen et al. 2007). Türkiye'de yazılı anlatım ile ilgili sorunlar dile getirilirken yazma konularının seçiminde öğrenci ilgi, ihtiyaçları ve gelişim özelliklerinin dikkate alınmadığı belirtilmektedir (Kurudayığlu \& Karadağ 2010). Ayrıca yazma çalışmalarının rastgele bir zamanda ve tüm öğrencilere aynı konuda bir kompozisyon yazdırılması şeklinde yürütülmesi eleştirilmektedir (Arıcı \& Ungan 
2008). Önemli gün ve haftalar ve atasözleri arasına sıkıştırılmış yazma konuları verilmesi öğrenciler için yazmayı ilgi çekici olmaktan çıkarmıştır. Yazma eğitiminde yaşanan sorunlar sıklıkla ele alınırken süreç temelli eğitim uygulamaları ve serbest konu seçimi konusunda yapılan çalışmalar yok denecek kadar azdır. Yazılı anlatımda konu seçimi, cinsiyet ve sınıf düzeyi ile ilgili yükseköğrenim düzeyinde Arıcı'nın (2009) ve ilköğretim düzeyinde Kurudayıoğlu ve Karadağ'ın (2010) çalışmaları bulunmaktadır. Arıcı (2009) araştırma verilerini yükseköğrenimdeki öğrencilerden anket yolu ile üç farklı tür için konu seçimlerini sorarak toplamıştır. Kurudayığlu ve Karadağ (2010) 1-8. sınıf öğrencilerine 6 farklı yazma konusu vermiş ve bunlardan bir konu/konular seçerek yazmalarını istemiştir. Bu araştırmanın bulgularına göre sınıf seviyelerine göre öğrencilerin seçtikleri konular değişiklik göstermiş ve üst sınıflarda daha fazla konuda yazılmıştır. Öğrenciler bizzat yaşadıkları önemli olay ve kişiler hakkında yazmayı tercih etmişlerdir. Özellikle atasözü ve özdeyiş ile ilişkili yazma konuları az tercih edilmiş olup, bu durum araştırmacılar tarafından sürekli öğrencilere yazması için verilen ve ilgi çekici olmayan konuları öğrencilerin yazmayı tercih etmediği şeklinde yorumlanmıştır.

Başarılı bir metin yazmanın birçok önkoşulu olmasına rağmen konu seçimi öğrencilere yazmayı sevdirmede önemli bir değişken olarak görülmektedir (Arıcı \& Ungan 2008). Öğrencilerin ilgi duydukları ve istedikleri bir konu hakkında yazmaları ve konu seçimi konusunda serbest bırakılmaları öğrencinin performansını arttırırken aynı zamanda, yukarıdaki alan yazınında da görüldüğü gibi, bazı sorunları beraberinde getirmektedir. Bu sorunların tespit edilip önceden önlem alınması yazma eğitiminin başarısına katkıda bulunacaktır. Süreç temeli yazma eğitiminde konu seçimi ile ilgili çalışmalar öğretmenler için de yol gösterici önemli bir kaynak olabilir. Bu çalışmanın amacı süreç temelli yazma eğitimi almış öğrencilerin yıllara ve cinsiyetlerine göre yaptıkları konu seçimlerini incelenmek ve değerlendirmektir. Bu bağlamda aşağıdaki araştırma sorularına yanıt aranmıştır:

- 2, 3 ve 4. sınıf öğrencilerinin öyküleyici anlatım için seçtikleri konular cinsiyet ve sınıf düzeyine göre bir farklılık göstermekte midir?

- 2 ve 4 . sınıf öğrencilerinin bilgilendirici metin için seçtikleri konular cinsiyet ve sinıf düzeyine göre bir farklılık göstermekte midir?

- 2, 3 ve 4. sınıf öğrencilerinin ikna edici metin için seçtikleri konular cinsiyet ve sinıf düzeyine göre bir farklılık göstermekte midir?

\section{Yöntem}

$\mathrm{Bu}$ çalışmanın amacı, süreç temelli yazma eğitimi almış öğrencilerin farklı metin türlerinde seçtikleri yazma konularını sınıf düzeyi ve cinsiyet değişkenlerine göre incelemektedir. Araştırma için nitel araştırma yöntemi seçilmiştir ve veriler içerik analizi yapılarak değerlendirilmiştir.

\section{Katılımcilar}

Çalışma Antalya merkez ilçede bulunan bir devlet okulunda yürütülmüştür. Okul seçiminde, okulun bulunduğu bölgedeki ailelerin sosyoekonomik düzeyi (orta düzeyde), üniversite ile işbirliği durumu ve çalışmayı yürütecek gönüllü öğretmenlerin bulunması dikkate alınmıştır. Araştırmanın çalışma grubu 2012-2013 eğitim öğretim yılında 2. sınıfa başlayan 6 şube arasından süreç temelli yazma eğitimi verilmek üzere rastgele seçilen öğrenciler oluşturmuştur.

\section{Veri Toplama Süreci}

Araştırmanın verileri 2, 3 ve 4 . sınıfta süreç temelli yazma eğitimi uygulamaları yapılan öğrencilerin yazdığı yazılardır. Araştırmacı tarafından yürütülen süreç temelli yazma eğitimi 
süresince zamanın önemli bir kısmı yazma için ayrılmış ve farklı türlerde metin yazma denemeleri yapılmıştır. Süreç, yazma konularını biriktirme, seçme ve geliştirme, taslak haline getirme, gözden geçirme, editörlük ve yayınlama/paylaşma olarak devam etmiş ve her bir türde yazılacak metinler için yaklaşık bir aylık zaman dilimi ayrılmıştır. Hazırlık ve planlama aşaması öğrencilerin bir metin türünde yazma için ihtiyaç duyacakları becerilerin kazandırılması için yapılan tüm çalışmaları içermiş ve öğrencilerin aynı zamanda yazma konularını biriktirdiği bir süreç olarak yürütülmüştür. Öğrenciler konu seçiminde özgür bırakılmış ve yazma amacını belirleme ve metin türüne uygun konu seçme becerileri de geliştirilmeye çalışılmıştır. $\mathrm{Bu}$ çalışmada öğrencilerin yazdıkları farklı metin türleri için seçtikleri konular incelenmiş ve değerlendirilmiştir. Tablo 1'de görüldügü gibi toplamda kızların yazmış olduğu 179 ve erkeklerin yazmış olduğu 126 farklı metin türünde toplam 305 metnin konusu incelenmiştir. Bitmemiş veya teslim edilmemiş toplam 52 yazı değerlendirme dışı tutulmuştur.

Tablo 1. Yazılan Metin Türlerinin Cinsiyet ve Sınıf Düzeyine Göre Dağılımı

\begin{tabular}{|l|c|c|c|c|c|c|c|}
\hline \multirow{2}{*}{ Kategori } & \multicolumn{2}{|c|}{ 2. Sınıf } & \multicolumn{2}{c|}{ 3. Sınıf } & \multicolumn{2}{c|}{ 4. Sınıf } & $\begin{array}{c}\text { Toplam } \\
\text { Konu } \\
\text { Sayıs1 }\end{array}$ \\
\cline { 2 - 8 } & Kız & Erkek & Kız & Erkek & Kız & Erkek & Öyk̈leyici Metin (kişisel) \\
\hline 30 & 22 & 29 & 21 & - & - & 102 \\
\hline Öyküleyici Metin (kurgu) & 12 & 8 & 15 & 12 & 15 & 7 & 69 \\
\hline Bilgilendirici Metin & 16 & 10 & - & - & 17 & 14 & 57 \\
\hline İkna Edici Metin & 15 & 8 & 13 & 11 & 17 & 13 & 77 \\
\hline Toplam & 73 & 48 & 57 & 44 & 49 & 33 & 305 \\
\hline
\end{tabular}

Öyküleyici metinler için öğrenciler 2 ve 3. sınıfta kendi yaşam öykülerinden yararlanmış 4 . sınıfta bu uygulamaya yer verilmemiştir. Kurgusunu kendilerinin yaptığ 1 öyküleyici metinlere her eğitim-öğretim yılında yer verilmiştir. 3. sınıfta yazılmış bilgilendirici metinlere yer verilmemiştir. Öğrenciler 3. sınıfta gözlem ve araştırmaya dayalı bilgi veren bir metin yazmışlar tüm uygulamalar bir konu üzerinde tasarlanmış ve etkinlikler çerçevesinde yürütülmüştür. Dolay1sıyla tüm öğrencilerin yazmış olduğu metinler kuvvet ve hareket konusu ile olduğu için araştırmaya dâhil edilmemiştir.

\section{Verilerin Analizi}

Dokümanlar içerik analizi yapılarak değerlendirilmiştir. İçerik analizi veriler (görüşmeler, alan notları ve dokümanlar) içindeki mesaj, anlam, imaj gibi konuların çeşitliliği ve sıklığı üzerinde durur. Süreç, doküman içerisindeki verilerin birbiri ile ilişkili olan özeliklerine göre kodlanması ve kategorilerin oluşturulması ile devam eder (Merriam 1998). Klasik içerik analizi daha çok durumu ya da olguyu açıklayacak teori ve araştırma alan yazını zayıf olduğunda kullanılır (Hsieh \& Shannon 2005). İçerik sayısal sunumlar yapılarak verildiğinden analizin doğası daha çok nicel araştırmalara yakındır (Ekiz 2009).

$\mathrm{Bu}$ çalışma için öğrencilerin yazmış olduğu metinlerin konuları kız ve erkek öğrenciler için ayrı olarak tablolar halinde yazılmış daha sonra konuların benzer özelliklerine göre biri alanında uzman iki araştırmacı tarafından sınıflandırılmıştır. Daha sonra oluşturulan bu sınıflandırmalara göre kategoriler isimlendirilmiştir.

\section{Bulgular}

$\mathrm{Bu}$ bölümde öğrencilerin seçtiği konular her bir metin türü için ayrı başlıklar altında verilmiştir. 
Analiz sonucunda oluşturulan kategoriler hem cinsiyet hem de sınıf düzeylerine göre tablolaştırılmış ve değerlendirilmiştir.

\section{Cinsiyete ve Sınıf Düzeylerine Göre Öyküleyici Metin Konuları}

Öğrencilerden, 2 ve 3. sınıfta öyküleyici metin yazma çalışması yapılırken, öncelikle kendi kişisel hayatlarında yaşadıkları bir olay seçmeleri ve yazmaları istenmiştir. Sonraki ay bir karakter üzerinden öykü kurgulamaları ve yazmaları istenmiştir.

Tablo 2'de görüldüğü gibi yaşanan özel bir gün ile ilişkili konuların (bisiklete bindiği ilk gün, teyzesinin düğünü, annesinin doğum yaptığı gün, balık tutmaya gittiği gün, vb.) her iki yılda da en çok tercih edilen konu olduğu görülmüştür. Özel gün kategorisinden kız öğrenciler doğum günü, yılbaşı, düğün, doğum gibi konular seçerken, erkekler kızlardan farklı olarak maç, yarış, araba sürme gibi konuları tercih etmişlerdir. Özel günler ile ilgili tercihler 3. sınıfta daha çok bir değişim ve yaşadıkları yenilik üzerine odaklanmış ve bu yönüyle farklılaşmıştır. Yenilik ile ilgili seçilen konular kız öğrencilerde aileyi ilgilendiren konular iken (yeni ev, taşınma, evin boyanması vb.) erkek öğrencilerde kişisel yeniliklerden (ilk defa gözlük takmaya başlanması gibi) seçilmiştir. 2. sınıfta kız ve erkekler tarafından benzer oranlarda seçilse de 3. sınıfta bu kategori erkek çocuklar tarafından daha çok tercih edilmiştir. Kişisel yaşanan kazalar (kolunun kırıldığı, bacağının tutulduğu, başının kanadığı gün vb.) daha çok kız öğrenciler tarafından tercih edilmiştir. Gezi kategorisinde (kampa, İzmir'e, hayvanat bahçesine, farklı şehirlere, yat turuna vb.) tanımlanabilecek konular 2. sınıfta daha çok yazılmıştır ve 3. sınıfta daha çok kız öğrenciler tarafindan tercih edilmiştir. Evde beslenen hayvanlar her iki y1lda sadece kız öğrenciler tarafindan tercih edilmiştir. Oyunlar ile ilgili konular erkek öğrenciler tarafindan daha çok tercih edilmiş 2. sınıfta daha çok futbol ve basketbol gibi takım oyunları seçilirken 3. sınıfta lego ve sanal oyunları içeren konular seçilmiştir.

Tablo 2. 2 ve 3. Sınıf Kişisel Öykü İçin Seçilen Konular

\begin{tabular}{|c|c|c|c|c|c|c|c|c|c|c|c|c|}
\hline \multirow{3}{*}{ Kategori } & \multicolumn{6}{|c|}{ 2. Sinıf } & \multicolumn{6}{|c|}{ 3. Sinif } \\
\hline & \multicolumn{2}{|c|}{$\mathrm{K}_{1 \mathrm{z}}$} & \multicolumn{2}{|c|}{ Erkek } & \multicolumn{2}{|c|}{ Toplam } & \multicolumn{2}{|c|}{$\mathrm{K}_{1 \mathrm{z}}$} & \multicolumn{2}{|c|}{ Erkek } & \multicolumn{2}{|c|}{ Toplam } \\
\hline & $\mathrm{f}$ & $\%$ & $\mathrm{f}$ & $\%$ & $\mathrm{f}$ & $\%$ & $\mathrm{f}$ & $\%$ & $\mathrm{f}$ & $\%$ & $\mathrm{f}$ & $\%$ \\
\hline Özel bir gün & 12 & 39 & 8 & 38 & 20 & 38 & 9 & 31 & 14 & 67 & 23 & 46 \\
\hline Özel gün (yenilik) & - & - & - & - & - & - & 4 & 14 & 3 & 14 & 7 & 14 \\
\hline Gezi & 9 & 29 & 7 & 33 & 16 & 31 & 5 & 17 & 1 & 04 & 6 & 12 \\
\hline $\begin{array}{l}\text { Kişisel yaşanan } \\
\text { kazalar }\end{array}$ & 5 & 16 & 3 & 14 & 8 & 15 & 4 & 14 & 0 & 0 & 4 & 8 \\
\hline Evdeki hayvanlar & 4 & 12 & 0 & 0 & 4 & 08 & 5 & 17 & 0 & 0 & 5 & 10 \\
\hline Takım oyunu & 1 & 03 & 3 & 14 & 4 & 08 & - & - & - & - & - & - \\
\hline Arkadaş & - & - & - & - & - & - & 2 & 06 & 1 & 04 & 2 & 4 \\
\hline Oyun & - & - & - & - & - & - & 0 & & 2 & 09 & 2 & 4 \\
\hline
\end{tabular}

Çocukların 2, 3 ve 4. sınıfta yazdığı öyküleyici metinlerin konularına bakıldığında (Tablo 3) korku ile baş etme ve kötü huylara sahip olan karakterlerin yaşadıkları ile ilgili konuların her sınıfta tercih edildiği görülmüştür. Korkuyu yenmeye çalışan çocuklar ile ilgili konular kızlar tarafından 2. sınıfta daha çok yazılmasına rağmen, erkeklerde bu konu ile ilgili yazıların oranı artarak devam etmiştir. Erkekler 4. sınıfta korkuyu, cesaretin sınanması ile birlikte ele alan konular seçmiştir. Kötü huylu çocuklar ile ilgili yazılan yazıları alt sınıflarda kızlar, üst sınıflara doğru erkekler daha çok tercih etmiştir. 2. sinıfta dalga geçen çocuklar yerine üst sinıfta çetele- 
şen çocuklar konusu üzerine yazmışlardır. Sorun çıkaran özellikler sadece kız çocuklar tarafından tercih edilmiştir. Her sınıfta farklı konulara yer veren öğrenciler olsa da kız öğrenciler iyi huylu özellikler ve beklentilerin yerine gelmesi ile ilgili yazmışlar farklı olarak erkekler yeteneklerini kötüye kullanan, engelli ve talihsiz çocuklar konusuna yer vermişlerdir.

Tablo 3. 2, 3 ve 4. Sınıf Öyküleyici Metin İçin Seçilen Konular

\begin{tabular}{|c|c|c|c|c|c|c|c|c|c|c|c|c|c|c|c|c|c|c|}
\hline \multirow{3}{*}{ Kategori } & \multicolumn{6}{|c|}{ 2. Sinif } & \multicolumn{6}{|c|}{ 3. Sinif } & \multicolumn{6}{|c|}{ 4. Sinif } \\
\hline & \multicolumn{2}{|c|}{$\mathrm{K}_{1 \mathrm{Z}}$} & \multicolumn{2}{|c|}{ Erkek } & \multicolumn{2}{|c|}{ Toplam } & \multicolumn{2}{|c|}{$\mathrm{K}_{1 \mathrm{Z}}$} & \multicolumn{2}{|c|}{ Erkek } & \multicolumn{2}{|c|}{ Toplam } & \multicolumn{2}{|c|}{$\mathrm{K}_{1 \mathrm{Z}}$} & \multicolumn{2}{|c|}{ Erkek } & \multicolumn{2}{|c|}{ Toplam } \\
\hline & $\mathrm{f}$ & $\%$ & $\mathrm{f}$ & $\%$ & $\mathrm{f}$ & $\%$ & $\mathrm{f}$ & $\%$ & $\mathrm{f}$ & $\%$ & f & $\%$ & $\mathrm{f}$ & $\%$ & $\mathrm{f}$ & $\%$ & $\mathrm{f}$ & $\%$ \\
\hline $\begin{array}{l}\text { Korkusunu yenen/ } \\
\text { cesareti sinanan } \\
\text { çocuk }\end{array}$ & 5 & 42 & 3 & 38 & 8 & 40 & 1 & 7 & 5 & 42 & 6 & 22 & 4 & 27 & 3 & 50 & 7 & 32 \\
\hline $\begin{array}{l}\text { Kötü huylu olan } \\
\text { çocuklar (yalancı, } \\
\text { kibirli, cimri, kıskanç, } \\
\text { hile yapan vb.) }\end{array}$ & 2 & 17 & 1 & 12 & 3 & 15 & 8 & 53 & 4 & 33 & 12 & 44 & 0 & 0 & 2 & 33 & 2 & 9 \\
\hline $\begin{array}{l}\text { Sorun çıkaran özel- } \\
\text { liklere sahip çocuk } \\
\text { (çekingenlik, unut- } \\
\text { kanlık, vb.) }\end{array}$ & 5 & 42 & 0 & 0 & 5 & 25 & - & - & - & - & - & 7 & 5 & 33 & 0 & 0 & 5 & 23 \\
\hline $\begin{array}{l}\text { Yeteneklerini kulla- } \\
\text { narak öğrenmeye } \\
\text { çalışan çocuk }\end{array}$ & 0 & 0 & 3 & 38 & 3 & 15 & - & - & - & - & - & - & - & - & - & - & - & - \\
\hline $\begin{array}{l}\text { İyi huylu olma (iyilik } \\
\text { yapma, affetme, } \\
\text { hatadan çabuk } \\
\text { dönme, vb.) }\end{array}$ & - & - & - & - & - & - & 6 & 40 & 2 & 17 & 8 & 30 & - & - & - & - & - & - \\
\hline $\begin{array}{l}\text { Beklentilerin yerine } \\
\text { gelmesi }\end{array}$ & - & - & - & - & - & - & - & - & - & - & - & - & 4 & 27 & 1 & 17 & 5 & 23 \\
\hline $\begin{array}{l}\text { Diğer (engellilik, } \\
\text { hayal kırıklığı, } \\
\text { talihsizlik vb.) }\end{array}$ & 0 & 0 & 1 & 12 & 1 & 5 & 0 & 0 & 1 & 8 & 1 & 4 & 2 & 13 & 1 & 17 & 3 & 14 \\
\hline
\end{tabular}

\section{Cinsiyete ve Sınıf Düzeyine Göre Bilgilendirici Metin Konuları}

Çocukların 2. ve 4. sınıfta yazdıkları bilgi veren metinler incelendiğinde 4. sınıfta daha farklı konularda bilgi verdikleri görülmüştür (Tablo 4). Fen (su döngüsü, su, elektrik, gezegenler, bitkiler, hava olayları vb.) konuları ve hayvanlar ile ilgili yazılar her iki yıl da tercih edilmiştir. Hayvanlar kategorisinde 2. sınıfta ev hayvanları (papağan, muhabbet kuşu, balık vb.) tercih edilirken 4. sınıfta kız öğrenciler daha çok vahşi olmayan hayvanlar (kelebekler, iskeletsiz hayvanlar, balıklar, vb.); erkek öğrenciler ise farklı olarak yırtıcı ve vahşi hayvanlar (kediler, örümcekler, vb.) hakkında da bilgi vermiştir. Ne nasıl yapılır kategorisinde kız öğrenciler tasarım, doğum günü partisi ve makyaj yapımı gibi konularda yazarken, erkek öğrenciler bisiklet bakımı ve yüzme konusunu seçmişlerdir. Erkek öğrencilerde ne nasıl yapılır ve fen konularına ilgi azalırken, farklı olarak sanal oyunlar ve araçlar hakkında yazmışlardır. 
Tablo 4. 2 ve 4. Sınıf Bilgilendirici Metin İçin Seçilen Konular

\begin{tabular}{|c|c|c|c|c|c|c|c|c|c|c|c|c|}
\hline \multirow{3}{*}{ Kategori } & \multicolumn{6}{|c|}{ 2. Sinif } & \multicolumn{6}{|c|}{ 4. Sinif } \\
\hline & \multicolumn{2}{|c|}{$\mathrm{K}_{1 \mathrm{z}}$} & \multicolumn{2}{|c|}{ Erkek } & \multicolumn{2}{|c|}{ Toplam } & \multicolumn{2}{|c|}{$\mathrm{K}_{1 \mathrm{z}}$} & \multicolumn{2}{|c|}{ Erkek } & \multicolumn{2}{|c|}{ Toplam } \\
\hline & $\mathrm{f}$ & $\%$ & $\mathrm{f}$ & $\%$ & $\mathrm{f}$ & $\%$ & $\mathrm{f}$ & $\%$ & $\mathrm{f}$ & $\%$ & $\mathrm{f}$ & $\%$ \\
\hline Ne nasıl yapılır & 6 & 38 & 3 & 30 & 9 & 35 & 2 & 12 & 0 & 0 & 2 & 6 \\
\hline Fen konuları & 5 & 31 & 3 & 30 & 8 & 31 & 6 & 35 & 1 & 7 & 7 & 23 \\
\hline Hayvanlar & 2 & 13 & 3 & 30 & 5 & 19 & 6 & 35 & 4 & 29 & 10 & 32 \\
\hline Çizgi film & 1 & 6 & 1 & 10 & 2 & 8 & - & - & - & - & - & - \\
\hline Oyunlar & - & - & - & - & - & - & 0 & & 4 & 29 & 4 & 13 \\
\hline Araçlar (Araba, roket) & - & - & - & - & - & - & 0 & & 4 & 29 & 4 & 13 \\
\hline $\begin{array}{l}\text { Diğer (lokanta, kardeş, gıda } \\
\text { zehirlenmesi, trafik vb.) }\end{array}$ & 2 & 13 & 0 & 0 & 2 & 8 & 3 & 18 & 1 & 7 & 4 & 13 \\
\hline
\end{tabular}

\section{Cinsiyete ve Sınıf Düzeyine Göre İkna Edici Metin Konuları}

Tablo 5'te görüldüğü gibi 2'den 4. sınıfa kadar olan ikna edici yazılar incelendiğinde çocuklar 2. sınıfta daha çok okulda, derslerde yaşanan sorunlar ve eksiklikler ile ilgili yazmışlardır. Bu durum daha çok kız öğrenciler tarafından dile getirilmiştir. Erkek öğrenciler okul dışı konularda kız öğrencilerden daha fazla yazmışlardır. Sorunların içerikleri cinsiyete göre değişmiştir. Beden eğitimi dersindeki sorunlar ile ilgili kız öğrenciler kız-erkek ayırımı konusuna, erkekler ise futbol oynayabilme konusuna değinmişlerdir. Okuldaki sorunlarda kızlar küfür ve argo kelimeler kullanımı konusuna değinirken erkekler büyük erkek çocukları ile bahçe kullanımında yaşanan sorunların çözümü konusunda ikna etmeye çalışmışlardır. 3. sınıfta okul ile ilişkili yazılar önemli bir biçimde azalırken alışkanlıklar (sigara kullanmamaya ikna etme, fazla şekerli yiyeceklerin tüketilmemesi vb.) ile ilgili konuları daha çok tercih etmişlerdir. 4. sınıfta alışkanlıkların daha geniş bir perspektiften (ormanların azaltılmaması, parkların çoğaltılması, spor yapma vb.) ele alındığı görülmüştür. 4. sınıfta ayrıca okul kuralları kategorisinde konu seçen çocuklar davranışlar ve sorunlar yerine daha çok okul kuralları ile ilgili (serbest giyinme, ders saatlerinin düzenlenmesi vb.) konular seçmişlerdir. Sosyal kurallar ve aile tutumları daha önce dar bir perspektiften ele alınırken 4. sınıfta daha fazla ve farklı boyutları ile değinilmiştir. Örneğin; sosyal kurallar bir önceki sınıfta hayata saygı ile ilgili iken 4. sınıfta çocuk cezaevleri, araba kullanma yaşı, sosyoekonomik gelir dağılımı vb. konular olmuştur. Ayrıca önceki sınıflarda ailesini yeni bir oyuncak (erkekler sanal oyunlar; kızlar yeni çıkan popüler oyuncaklar) alma konusunda ikna etmeye çalışırken 4. sınıfta anne babaların çocuklarının her isteğine hemen hayır dememeleri konusunda ikna etmeye çalışmışlardır. 
Tablo 5. 2, 3 ve 4. Sınıf İkna Edici Metin İçin Seçilen Konular

\begin{tabular}{|c|c|c|c|c|c|c|c|c|c|c|c|c|c|c|c|c|c|c|}
\hline \multirow{3}{*}{ Kategori } & \multicolumn{6}{|c|}{ 2. Sinıf } & \multicolumn{6}{|c|}{ 3. Sinif } & \multicolumn{6}{|c|}{ 4. Sinif } \\
\hline & \multicolumn{2}{|c|}{$\mathrm{K}_{1 \mathrm{Z}}$} & \multicolumn{2}{|c|}{ Erkek } & \multicolumn{2}{|c|}{ Toplam } & \multicolumn{2}{|c|}{ K1z } & \multicolumn{2}{|c|}{ Erkek } & \multicolumn{2}{|c|}{ Toplam } & \multicolumn{2}{|c|}{$\mathrm{K}_{1 \mathrm{z}}$} & \multicolumn{2}{|c|}{ Erkek } & \multicolumn{2}{|c|}{ Toplam } \\
\hline & $\mathrm{f}$ & $\%$ & $\mathrm{f}$ & $\%$ & $f$ & $\%$ & $\mathrm{f}$ & $\%$ & $\mathrm{f}$ & $\%$ & $\mathrm{f}$ & $\%$ & $\mathrm{f}$ & $\%$ & $\mathrm{f}$ & $\%$ & $\mathrm{f}$ & $\%$ \\
\hline $\begin{array}{l}\text { Beden eğitimi } \\
\text { dersindeki sorunlar }\end{array}$ & 5 & 33 & 1 & 13 & 6 & 26 & - & - & - & - & - & - & - & - & - & - & - & - \\
\hline Okuldaki sorunlar & 4 & 27 & 1 & 13 & 5 & 22 & - & - & - & - & - & - & - & - & - & - & - & - \\
\hline $\begin{array}{l}\text { Okulda kütüphane } \\
\text { olması }\end{array}$ & 2 & 13 & 1 & 13 & 3 & 13 & - & - & - & - & - & - & - & - & - & - & - & - \\
\hline $\begin{array}{l}\text { Okul kuralları } \\
\text { (serbest giyme, ders } \\
\text { saatleri, yeni dersler, } \\
\text { vb.) }\end{array}$ & - & - & - & - & - & - & 1 & 8 & 1 & 9 & 2 & 8 & 5 & 29 & 4 & 31 & 9 & 27 \\
\hline $\begin{array}{l}\text { Yararlı alışkanlıklar } \\
\text { (iyi beslenme, kitap } \\
\text { dergi okuma } \\
\text { alışkanlığı vb.) }\end{array}$ & - & - & - & - & - & - & 4 & 31 & 3 & 27 & 7 & 29 & - & - & - & - & - & - \\
\hline $\begin{array}{l}\text { Zararlı alışkanlıklar } \\
\text { (sigara, çikolata vb.) }\end{array}$ & - & - & - & - & - & - & 2 & 15 & 2 & 18 & 4 & 17 & - & - & - & - & - & - \\
\hline $\begin{array}{l}\text { Sağlıklı hayat ve } \\
\text { çevre (sigara, } \\
\text { orman, oyun } \\
\text { parkları vb.) }\end{array}$ & - & - & - & - & - & - & - & - & - & - & - & - & 6 & 35 & 4 & 31 & 10 & 30 \\
\hline $\begin{array}{l}\text { Evdeki sorunların } \\
\text { çözümü ve } \\
\text { değişiklik }\end{array}$ & 3 & 20 & 2 & 25 & 5 & 22 & - & - & - & - & - & - & & & & & & \\
\hline $\begin{array}{l}\text { Aile / anne baba } \\
\text { tutumları }\end{array}$ & - & - & - & - & - & - & - & - & - & - & - & - & 2 & 12 & 1 & 8 & 3 & 10 \\
\hline $\begin{array}{l}\text { Sosyal kurallar } \\
\text { (araba kullanma } \\
\text { yaşı, çocuk } \\
\text { cezaevleri, vb.) }\end{array}$ & - & - & - & - & - & - & - & - & - & - & - & - & 3 & 18 & 4 & 31 & 7 & 21 \\
\hline Oyuncak & 1 & 7 & 3 & 38 & 4 & 17 & 1 & 8 & 2 & 18 & 3 & 13 & - & - & - & - & - & - \\
\hline $\begin{array}{l}\text { Mekan (lokanta, } \\
\text { firın, otel) }\end{array}$ & - & - & - & - & - & - & 2 & 15 & 1 & 9 & 3 & 13 & - & - & - & - & - & - \\
\hline $\begin{array}{l}\text { Diğer (film, } \\
\text { matematik, hayata } \\
\text { sayg1, uzaylılar vb.) }\end{array}$ & - & - & - & - & - & - & 3 & 23 & 2 & 18 & 5 & 21 & 1 & 6 & 0 & 0 & 1 & 3 \\
\hline
\end{tabular}

\section{Sonuç ve Tartışma}

Cinsiyet ve yazma ile ilgili çalışmalarda iki önemli konu ön plana çıkmaktadır. Bunlardan ilki öğrencilerin yazılarındaki benzerlik ve farklılıkların araştırılması, ikincisi ise kız ve erkeklerin yazma başarılarını etkileyen faktörlerin belirlenmesidir (Jones 2011). Bu çalışma yazma konusu seçimi ile ilgili cinsiyet farklılıklarını ve benzerlikleri ortaya koyması açısından önemlidir. İlköğretim Türkçe programlarının süreç temelli yazma eğitiminin bileşenlerini içermesine rağmen ürün odaklı bir yazma eğitiminin sürdürülüyor olması nedeni ile yazma eğitiminde istenilen başarıya ulaşılmadığ belirtilmekle birlikte (Tabak \& Göçer 2013) süreç temelli yazma konusunda Türkiye'de yapılan çalışmalar artarak devam etmektedir. Bu çalışmanın sonuçları yazılı anlatım çalışmalarında konu seçimi konusunda yapılacak uygulamalar için yol göstericidir. 
$\mathrm{Bu}$ çalışmanın bulgularına göre hem kız hem de erkek öğrenciler tarafindan tercih edilen konular aynı kategoride yer alsa bile cinsiyete göre farklılaşmıştır. Ayrıca üst sınıflara doğru konu sayılarının arttığı ve farklılaştığı görülmektedir. Bu araştırmanın bulguları erkekler ve kızların konu tercihinde farklılaştığı ve yazma konularının kalıplaşmış cinsiyet rollerini yansıttığı ile ilgili araştırma bulgularını desteklemektedir (Kamler 1993; Fleming 1995; Freedman 1995; Simmons 1997; Peterson 2000).

Her y1lda hem kızlar hem de erkekler tarafindan tercih edilen konular incelendiğinde öyküleyici metinlerde özel bir gün konusu her iki grup içinde en fazla tercih edilen konulardan olmuştur. Bu durum konu seçiminde öğrencilerin daha çok bizzat yaşadıkları önemli olaylar hakkında yazmayı tercih ettikleri ile ilgili bulguları desteklemektedir (Kurudayığlu \& Karadağ 2010). Özel gün kategorisinde seçilen konular cinsiyete göre farklılaşmıştır. Ayrıca korku ile baş etme ve kötü huylara sahip çocukların yaşadığı sorunlar tüm yıllar tercih edilen konular arasındadir.

Cinsiyete göre farklılık gösteren konu tercihleri incelendiğinde kişisel kazalar ve hayvanlar ile ilgili yazılar sadece kızlar tarafından tercih edilmiştir. Oyunlar ve arkadaşları ile ilgili konular sadece erkekler tarafindan tercih edilen konulardandır. Sorun çıkaran özelliklere sahip çocuklar sadece kızlar tarafından tercih edilmiş ayrıca 4. sınıfta erkekler kötü huyları tercih ederken, kızlar yine sorun çıkaran ama kötü olmayan özellikler ile ilgili yazmayı tercih etmişlerdir. Farklı olarak erkekler yeteneklerini kötüye kullanan, engelli ve talihsiz çocuklar konusuna yer vermişlerdir. Bu durum erkeklerden farklı olarak kızların daha özel ve kendilerine yakın alanlar ile ilgili yazdıkları ve erkeklerin aksiyon içerecek konuları tercih ettiği ile ilgili araştırma bulgularını desteklemektedir (Peterson 2000).

Yazmayı öğrenme ve metin üretiminde dilin, sosyokültürel değerlerin ve sosyal kimlik gelişimin etkisi önemlidir (Janks 2000; Jones 2011). Başkaları ile ilişkileri ve dili kullanım biçimleri öğrencilerin cinsiyet ile ilgili kimliklerini yapılandırmaktadır. Peterson (2002) erkek öğrencilerinin eril özelliklerini seçtikleri yazma konuları ile belirginleştirdiklerini söylemektedir. Örneğin romantik ya da duygusal içeriği olan konular seçmek yerine spor ile ilgili yazmayı tercih etmektedirler. Benzer bir biçimde bilgi veren metinlerde erkek öğrencilerde fen konularına ilgi azalırken araçlar ve oyunlar konusu artmıştır. İkna edici yazılarda erkek öğrenciler okul dışı konularda kız öğrencilerden daha fazla yazmışlardır. Sorunların içerikleri cinsiyete göre değişmiştir. Beden eğitimi dersindeki sorunlar ile ilgili kız öğrenciler kız-erkek ayırımı konusuna, erkekler ise futbol da oynayabilme konusuna değinmişlerdir. Okuldaki sorunlarda kızlar küfür ve argo kelimeler kullanımı konusuna değinirken erkekler büyük erkek çocukları ile bahçe kullanımında yaşanan sorunların çözümü konusunda ikna etmeye çalışmışlardır.

Öyküleyici anlatımda kişisel konular ele alınırken bilgi veren metinler için sosyal içerikli konuların çok az seçildiği görülmüş̧ür. İkna edici yazılar için ise az da olsa öğrencilerin sosyal sorunlar ve eşitsizlikler konusunda yazmayı tercih ettiği görülmüştür. Öğrencilere sosyal içerikli konular hakkında özellikle firsat verilmediğinde bu konuda yazmadıkları hatta özellikle cinsiyet eşitsizliği yaratacak rolleri ön plana çıkaran yazma konuları seçtikleri görülmektedir. Öğrencilerin yazma gelişimini desteklediği ve öğrenci merkezli olması nedeni ile bireysel öğrenme ve motivasyonu arttırdığı için süreç temelli yazma eğitiminde kullanılan stratejilerin her zaman tehlikesiz ve yararlı olmadığı eleştirilmektedir (Lensmire 1992; Deshon 1997). Süreç temelli yazma programlarına tekrar farklı bir gözle bakılması gerektiği vurgulanmaktadır (Luke 1991). Özellikle eleştirel okuryazarlı̆̆ ön plana çıkaran, sorgulayıcı, diyalog eksenli ve sosyal hayata aktif katılımının önünü açan bir eğitimin verilmesi gerektiğinin altı çizilmektedir (Shannon 1995). Öğrencilerin yazdıkları metinleri farklı bir gözle inceleyip okul ve sosyal hayatta çatışma 
ve eşitsizlik yaratan sorun ve konular hakkında daha eleştirel olmaları sağlanmalı ve bu konular sinıf ortamında sorgulanmadan geçilmemelidir.

Yıllara göre farklılaşan konular incelendiğinde benzer ve aynı kategorideki konuların içeriğinin yıllara göre farklılaştığı görülmüştür. Farklı konularda yazılan yazıların 4. sınıfta daha çok arttığı görülmüştür. Özel gün ile ilgili tercih edilen yazılar sonraki yıllarda içeriği yenilik ile ilgili olan günler tercih edilmiştir. Erkek çocuklar ilk y1llarda korku ile baş etme konusunu seçerken sonraki yıllarda içeriği cesareti sınanan çocuklar hakkında yazmıştır. Dalga geçen çocuklardan çeteleşen çocuklara doğru bir tercih söz konusudur. Bilgi veren metinlerde ise öğrenciler 4. sınıfta daha farklı konularda bilgi vermişlerdir. Fen konuları ve hayvanlar konusu 4. sınıfta artan ve her yıl tercih edilen konulardandır. Alışkanlıklar, sosyal kurallar ve aile tutumları daha önce dar bir perspektiften ele alınırken 4. sınıfta daha fazla ve farklı boyutları ile ele alındığı görülmüştür. Bu durum öğrencilerin ilgi ve ihtiyaçlarının yıllara göre değiştiği ile açıklanabilir. Öğrencilerin bilgi sahibi olduğu, ilgi ve merak ettikleri konulardan başlayarak üst sınıflara doğru daha sosyal içerikli ve araştırmaya dayalı konular seçmelerine firsat tanınmalıdır. Bununla birlikte cinsiyetin konu seçimi üzerine etkisi göz ardı edilmeden öğrencilerin kendinin ve arkadaşlarının konu tercihlerini sorgulama, farklı bakış açıları kullanarak irdeleme, farklılıkların kaynakları hakkında konuşma gibi eleştirel okuryazarlığın (Lewison et al. 2002) farklı boyutları kullanılarak daha iyi bir yazarlık eğitimi verilebilir.

\section{KAYNAKÇA}

Arıcı A. F. \& Ungan S. (2008). "Konu Seçiminin Yazma Becerisine Etkisi”. Çağdaş Eğitim Dergisi 33/357 (2008) 19-24.

Arıcı A. F. (2009). "Preferred Writing Topics of Preservice Teachers". European Journal of Educational Studies 1/2 (2009) 95-99.

Deshon J. A. P. (1997). "Innocent and Not-so-innocent Contributions to Inequality: Choice, Power, and Insensitivity in a First-Grade Writing Workshop”. Language Arts 74/1 (1997) 12-16.

Dyson A. H. (1995). "The Courage to Write: Child Meaning Making in a Contested World". Language Arts 72 (1995) 324-333.

Ekiz D. (2009). Bilimsel Araştırma Yöntemleri. Ankara 2009.

Emig J. (1971). The Composing Processes of Twelfth-Graders. Urbana, IL 1971.

Fleming S. (1995). “Whose Stories are Validated?”. Language Arts 72/8 (1995) 590-596.

Flower L. \& Hayes J. R. (1981). “A Cognitive Process Theory of Writing”. College Composition and Communication 32/4 (1981) 365-387.

Flowerday T., Schraw G. \& Stevens J. (2004). “The Role of Choice and Interest in Reader Engagement”. Journal of Experimental Education 72 (2004) 93-114.

Freedman R. (1995). “The Mr. and Mrs. Club: The Value of Collaboration in Writer's Workshop”. Language Arts 72 (1995) 97-104.

Graves D. (1983). Writing: Teachers and Children at Work. Portsmouth, NH 1983.

Hsieh H. \& Shannon S. E. (2005). "Three Approaches to Qualitative Content Analysis”. Qualitative Health Research 15/9 (2005) 1277-1288.

Janks H. (2000). "Domination, Access, Diversity and Design: A Synthesis for Critical Literacy Education”. Educational Review 52 (2000) 175-186.

Jones S. (2011). "Mapping the Landscape: Gender and the Writing Classroom”. Journal of Writing Research 3/3 (2011) 163-179.

Kamler B. (1993). "The Construction of Gender in Process Writing Classrooms”. Ed. P. Gilbert. Gender Stories and the Language Classroom (1993) 41-54. Victoria.

Keenan J., Solsken J. \& Willett J. (1999). ““Only Boys can Jump High’: Reconstructing Gender Relations 
in a First/Second-Grade Classroom”. Ed. B. Kamler. Constructing Gender and Difference (1999) 3370. Cresskill, NJ.

Kurudayığlu M. \& Karadağ Ö. (2010). "İlköğretim Öğrencilerinin Yazılı Anlatımlarının Konu Seçimleri Açısından İncelenmesi”. Mustafa Kemal Üniversitesi Sosyal Bilimler Enstitüsü Dergisi 7/13 (2010) 192-207.

Lee J. W. (1987). “Topic Selection in Writing: Aprecarious but Practical Balancing Act”. The Reading Teacher 41/2 (1987) 180-184.

Lensmire T. (1994). When Children Write: Critical Revisions of the Writing Workshop. New York 1994.

Lewison M., Flint A. S. \& Van Sluys K. (2002). "Taking on Critical Literacy: The Journey of Newcomers and Novices". Language Arts 79 (202) 382-392.

Luke A. (1991). “Literacy as Social Practices”. English Education 23 (1991) 131-147.

McAuliffe S. (1994). "Toward Understanding One Another: Second Graders' Use of Gendered Language and Story Styles”. Reading Teacher 47/4 (1994) 302-310.

McCutchen D. (1986). "Domain Knowledge and Linguistic Knowledge in the Development of Writing Ability". Journal of Memory and Language 25 (1986) 431-444.

Merriam S. (1998). Qualitative Research and Case Study Applications in Education. San Francisco 1998.

Murray D. (1984). “Teaching Writing as a Process not Product”. Ed. R. L. Graves. Rhetoric and Composition: A Sourcebook for Teachers and Writers (1984) 89-94. UpperMontclair, NJ.

Peterson S. (2000). "Fourth, Sixth, and Eighth Graders' Preferred Writing Topics and Identification of Gender Markers in Stories”. Elementary School Journal 101/1 (2000) 79-100.

Peterson S. (2002). "Gender Meanings in Grade Eight Student’s Talk About Classroom Writing”. Gender and Education 14 (2002) 351-366.

Peterson S. (2006). "Influence of Gender on Writing Development”. Eds. C. A. MacArthur, S. Graham \& J. Fitzgerald. Handbook of Writing Research (2006) 311-323. New York.

Shannon P. (1995). Text, Lies, \& Videotape: Stories about Life, Literacy and Learning. Portsmouth, NH 1995.

Shippen M. E., Houchins D. E., Puckett D. \& Ramsey M. (2007). "Preferred Writing Topics of Urban and Rural Middle School Students”. Journal of Instructional Psychology 34/1 (2007) 59-66.

Simmons J. (1997). "Attack of the Killer Baby Faces: Gender Similarities in Third Grade Writing”. Language Arts 74 (1997) 116-123.

Tabak G. \& Göçer A. (2013). “6-8. Sınıflar Türkçe Dersi Öğretim Programının Ürün ve Süreç Odaklı Yazma Yaklaşımları Çerçevesinde Değerlendirilmesi”. Ahi Evran Üniversitesi Kırşehir Eğitim Fakültesi Dergisi (KEFAD) 14/2 (2013) 147-169.

Tuck D., Bayliss V. \& Bell M. (1985). "Analysis of Sex Stereo Typing in Characters Created by Young Authors”. Journal of Educational Research 78/4 (1985) 248-252. 